\title{
Evaluation of Mandibular Foramen Localization with Three- Dimensional Computed Tomography in Adult Individuals
}

\section{Erişkin Bireylerde Mandibular Foramen Lokalizasyonunun Üç Boyutlu Bilgisayarlı Tomografi ile Değerlendirilmesi}

\author{
๑ Abdülkadir Bilir ${ }^{1}$, Ozan Turamanlar ${ }^{1}$, ๑ Hilal Güzel ${ }^{1}$, ๑ Emre Kaçar ${ }^{2}$ \\ ${ }^{1}$ Afyonkarahisar Health Sciences University Faculty of Medicine, Department of Anatomy, Afyonkarahisar, Turkey \\ ${ }^{2}$ Private Doruk Setbaşı Medical Center, Division of Radiology, Bursa, Turkey
}

Background: Mandibular anesthesia is a frequently preferred anesthesia technique in the restorative, pulpal and surgical treatments of milk molars and permanent molars, as well as in mandible fractures and all surgical interventions that involve the mandible. In this reason, localization differences of mandibular foramen should be taken into consideration while applying mandibular anesthesia technique in patients. The aim of this study is to evaluate the localization of the mandibular foramen in living adults with three-dimensional computed tomography images.

Materials and Methods: The study was carried out retrospectively on the radiologic images of 200 randomly selected adult individuals who had computed tomography examination for paranasal sinus and/or head and neck pathologies. The closest vertical (A) and horizontal (C) distances from mandibular foramen to margins of mandibular ramus and total vertical (B) and horizontal (D) distances of mandibular ramus were measured bilaterally in the edandate and dendate individuals, and the $A / B$ and C/D ratios were evaluated.

Results: When the measurements of dentate and edentate mandibles were compared, a statistically significant difference was found in all parameters (A, B, C, D, A/B, C/D) and it was determined that the measurements of dentate mandibles were larger than those of edentate mandibles. When the mandibular measurements were compared according to the sides (left/right), the $A$ and $D$ measurements and $A B$ ratio in the right dentate mandibles and the $B, C, D$ measurements and $A B, C D$ ratios in the right edentate mandibles were statistically significantly larger than the left side. When the measurements were compared by gender, the B, C, D measurements and $A B$ ratio of male dentate mandibles were statistically significantly higher than females.

Conclusion: It was determined that mandible measurements of dentate cases were larger than edentate mandible. Mandibular ramus can be asymmetrical and ramus morphometers may be affected by gender within the clinical syndromes. This study demonstrates that the anatomical landmarks determined to find the target area for nerve block and to determine the safety zone for the ramus osteotomy lines can vary depending on the presence of the teeth.

Keywords: Adult population, mandibular foramen, three-dimensional computed tomography

Amaç: Mandibular anestezi, süt ve kalıcı azı dişlerinin pulpa, restoratif ve cerrahi tedavilerinde, mandibula kırıklarında ve mandibulayı ilgilendiren tüm cerrahi girişimlerde sıklıkla tercih edilen bir anestezi tekniğidir. Bu nedenle hastalarda mandibular anestezi tekniği uygulanırken foramen mandibulae lokalizasyon farklılıkları dikkate alınmalıdır. Bu çalışmanın amacı, yaşayan erişkinlerde foramen mandibulaenin lokalizasyonunun üç boyutlu bilgisayarlı tomografi görüntüleri ile değerlendirmesidir.

Gereç ve Yöntemler: Çalışma, paranazal sinüs ve/veya baş-boyun patolojileri için bilgisayarlı tomografi incelemesi yapılan rastgele seçilmiş 200 erişkin bireyin radyolojik görüntüleri üzerinde retrospektif olarak gerçekleştirildi. Foramen mandibulaedan ramus mandibulae kenarlarına en yakın dikey $(A)$ ve yatay mesafeler $(C)$ ve ramus mandibulaenın toplam dikey (B) ve yatay mesafeleri (D) dişli ve dişsiz bireylerde bilateral olarak ölçüldü.

Bulgular: Dişli ve dişsiz mandibula ölçümleri karşılaştırıldığında, tüm parametrelerde (A, B, C, D, A/B, C/D) istatistiksel olarak anlamlı bir fark bulundu ve dişli mandibula ölçümlerinin dişsiz mandibulalara göre daha büyük olduğu belirlendi. Mandibular ölçümler laterilizasyona (sol/sağ) göre karşılaştırıldığında, sağ diş̧i mandibulada $A$ ve $D$ ölçümleri ve $A B$ oranı ile sağ dişsiz mandibulada $B, C, D$ ölçümleri ve $A B, C D$ oranları istatistiksel olarak anlamlı derecede sol taraftan daha büyük bulundu. Ölçümler cinsiyete göre karşılaştırıldığında erkek dişli mandibulanın B, C, D ölçümleri ve AB oranı kadınlara göre istatistiksel olarak anlamlı derecede yüksekti.

Address for Correspondence: Abdülkadir Bilir, Afyonkarahisar Health Sciences University Faculty of Medicine, Department of Anatomy, Afyonkarahisar, Turkey Phone: +0 2722463301 E-mail: fztabdulkadirbilir@gmail.com ORCID ID: orcid.org/0000-0003-0633-9542

Received: 07.09.2021 Accepted: 12.10.2021 
Sonuç: Dişli olguların mandibula ölçümlerinin dişsiz mandibuladan daha büyük olduğu ve klinik sendromlar içerisinde ramus mandibulaenın asimetrik olabileceği ve ramus morfometrelerinin cinsiyetten etkilenebileceği belirlendi. Bu çalışma, sinir bloğu için hedef alanı bulmak ve ramus mandibulaenın osteotomi hatları için güvenlik bölgesini belirlemek için anatomik işaretlerin dişlerin varlığına bağlı olarak değişebileceğini göstermektedir.

Anahtar Kelimeler: Erişkin popülasyon, mandibular foramen, üç boyutlu bilgisayarlı tomografi

\section{Introduction}

The mandibular foramen is located on the inner surface of the ramus of mandible and forms the entrance part of the mandibular canal. This canal starts from the ramus of mandible and opens out as mental foramen on the outer face of the body of mandible. The inferior alveolar nerve, inferior alveolar artery and inferior alveolar vein pass through this canal together. The inferior alveolar nerve provides sensory innervation to the lower teeth, as well as the lower lip, gingiva and some skin on the lower face. The inferior alveolar artery and vein supply these regions $(1,2)$.

Mandibular anesthesia is a frequently preferred anesthesia technique in the restorative, pulpal and surgical treatments of milk molars and permanent molars, as well as in mandible fractures and all surgical interventions that involve the mandible. Localization differences of mandibular foramen should be taken into consideration while applying mandibular anesthesia technique in edentulous patients. Wrong anesthesia results in many complications such as trismus and facial paralysis (3).

The current literature on mandibular foramen is mostly based on the anatomic data, surgical landmarks derived from dry human skulls, panoramic and radiologic images $(4,5)$. There are a lot of limitations as shrinkage and fracture of subtle structures or magnification, distortion and reproducibility of radiographic images in measurements of these studies $(6,7,8,9)$. While there are enough research and data sets for the mandible surgery of the healthy population in the clinic, there is a lack of data in the mandible surgery of geriatric patients, especially edentate patients because consequences of tooth loss on the maxillary and mandibular alveolar bone are well known. However, those morphological changes require additional examination. As a solution to the limitations mentioned above, the use of three-dimensional (3D) computed tomography (CT) reconstruction technique in clinical trials has become widespread $(5,10,11,12)$.

The aim of this study is to evaluate the localization of mandibular foramen in living adults with three-dimensional computed tomography.

\section{Material and Methods}

The study was carried out on the radiologic images of 200 randomly selected adult individuals (91 female, 109 male) aged
18-65 years, who had CT examination for paranasal sinus and/ or head and neck pathologies in the department of radiology. Those with mandibular pathology or malformation, and artifact on CT images were excluded from this study. In retrospective archive search, it is not obligatory to obtain patient consent. The study was carried out as a retrospective archive search in accordance with the Declaration of Helsinki after obtaining approval from the Local Ethics Committee of Afyonkarahisar Health Science University (KAEK/2015/09-240).

Scans were performed with 80-row MDCT scanner (Aquilion Prime, Toshiba Medical Systems, Nasu, Japan). The CT protocol was as follows: Peak kilovoltage $120 \mathrm{kVp}$, tube current 150-165 minimum (min) and maximum (max) collimation: $2.5 \mathrm{~mm}$, slice thickness: $3 \mathrm{~mm}$ and rotation time: $0.75 \mathrm{~s}$. Images that included the mandibular foramen were retrospectively analyzed on a workstation (Aquarius, TeraRecon Inc., San Mateo, CA, USA). Reconstruction images with $0,5 \mathrm{~mm}$ slice thickness were created from the server images with $3 \mathrm{~mm}$ slice thickness. Multiplanar reconstruction and $3 \mathrm{D}$ volume rendering images were obtained from sections with $0.5 \mathrm{~mm}$ slice thickness. In 3D images, the distance was measured from the mandibular foramen to the specific points on both sides of mandible. Measurements (Figure 1):

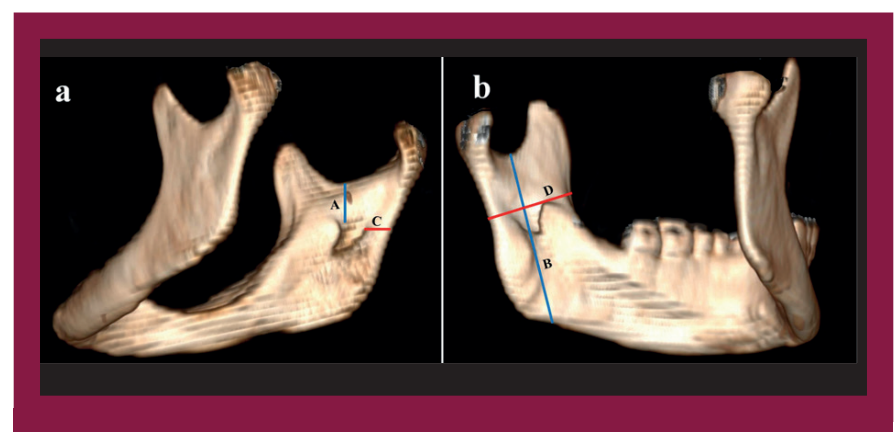

Figure 1. a. The closest vertical and horizontal distances on ramus of edentate mandible from mandibular foramen to margins. b. Total vertical and horizontal distances on ramus of edentate mandible (A; The closest vertical linear distance from the superior edge of the mandibular foramen (in line with apex of the lingula) to the mandibular notch, B; Vertical linear distance between the mandibular notch and the base of mandible passing on the mandibular foramen, C; The closest horizontal linear distance between the posterior edge of the mandibular foramen and the posterior edge of the mandibular ramus, D; Horizontal linear distance between the anterior and posterior edges of the mandibular ramus passing on the mandibular foramen) 
- (A) - The closest vertical linear distance from the superior edge of the mandibular foramen to the mandibular notch.

- (B) - Vertical linear distance between the mandibular notch and the base of mandible passing on the mandibular foramen.

- (C) - The closest horizontal linear distance between the posterior edge of the mandibular foramen and the posterior edge of the mandibular ramus.

- (D) - Horizontal linear distance between the anterior and posterior edges of the mandibular ramus passing on the mandibular foramen.

- A/B ratio

- $\mathrm{C} / \mathrm{D}$ ratio

\section{Statistical Analysis}

Statistical analysis of the data was done with SPSS version 20.0 package program. Statistical analysis included means and standard deviations. The Kolmogorov-Smirnov test was used to evaluate the suitability of data for normal distribution and it was determined that data were not homogeneous. The Mann-Whitney $U$ test was used to evaluate the significance of the differences by making comparisons between both mandibular foramen measurements of the same person, genders, and dentate/edentate mandibles measurements. The relationship between age groups and evaluation parameters was analyzed with the Pearson's correlation test. The results were evaluated in $95 \%$ confidence interval and data with $p$ value less than $0.05(p<0.05)$ were considered statistically significant.

\section{Results}

In our study, CT images of 100 dentate cases (54 male/46 female) and 100 edentate cases ( 55 male $/ 45$ female) randomly selected from the healthy population were evaluated. The mean age of dentate cases was $36.57 \pm 13.56$ years while the mean age of edentate cases was $65.65 \pm 11.14$ years. Morphometric measurement data were shown in millimeters as mean and standard deviations.

When the mandibular measurements were compared according to the sides (left/right), the $A$ and $D$ measurements and $A B$ ratio in the right dentate mandibles $(p<0.001$, $p<0.001, p<0.001$ respectively) and the $B, C, D$ measurements and $A B, C D$ ratios in the right edentate mandibles were statistically significantly larger than the left side $(p=0.037$, $p=0.057, p<0.001, p<0.001, p=0.033$, respectively) (Table 1). When the measurements were compared by gender, the $B$, $C, D$ measurements and $A B$ ratio of male dentate mandibles were statistically significantly higher than females $(p<0.001$, $p=0.005, p<0.001, p=0.012$, respectively) (Table 2). When the measurements of dentate and edentate mandibles were compared, a statistically significant difference was found in all parameters (A, $B, C, D$ measurements and $A B, C D$ ratios) and it was determined that the measurements of dentate mandibles were larger than those of edentate mandibles $(p<0.001, \quad p=0.002, p<0.001, p=0.014, p<0.001, p<0.001$, respectively) (Table 3 ).

\section{Discussion}

Mandibular anesthesia is a frequently preferred anesthesia technique in the restorative and surgical treatments of the jaw and molars (3). The most common complication in these treatments is nerve injury. This damage is often temporary or permanent. Among nerve injuries, it has been reported that injury to the IAN occurs more frequently due to its anatomical position. It is needed to visualize this area before surgical procedures, as it cannot be easily palpated by hand and can cause severe complications in IAN damage. Therefore, the location of the mandibular foramen should be determined by preoperatively examining the panoramic and radiologic images, and its relationship with the surrounding anatomical structures should be evaluated. Accordingly, the safe zone, which is the area above and behind the mandibular foramen, should be determined in mandibular ramus osteotomies, surgical treatments of the jaw and molars $(13,14)$. In this context, we aimed to evaluate the localization of the mandibular foramen in adult individuals living with or without teeth with three-dimensional computed tomography.

\begin{tabular}{|c|c|c|c|c|}
\hline & & Left & Right & p \\
\hline \multirow{6}{*}{ Dentate } & A & $18.58 \pm 3.36$ & $21.09 \pm 4.28$ & $p<0.001^{*}$ \\
\hline & B & $50.76 \pm 4.85$ & $51.91 \pm 5.17$ & 0.068 \\
\hline & C & $12.77 \pm 1.77$ & $13.22 \pm 1.95$ & 0.159 \\
\hline & D & $27.82 \pm 3.34$ & $29.76 \pm 3.39$ & $p<0.001^{*}$ \\
\hline & $A / B$ & $0.37 \pm 0.06$ & $0.41 \pm 0.07$ & $p<0.001^{*}$ \\
\hline & C/D & $0.46 \pm 0.06$ & $0.44 \pm 0.05$ & 0.069 \\
\hline \multirow{6}{*}{ Edentate } & A & $15.81 \pm 2.50$ & $15.54 \pm 2.58$ & 0.509 \\
\hline & B & $49.87 \pm 4.72$ & $49.87 \pm 4.82$ & 0.954 \\
\hline & C & $11.43 \pm 2.51$ & $11.51 \pm 2.53$ & 0.693 \\
\hline & D & $27.66 \pm 3.45$ & $28.23 \pm 3.64$ & 0.271 \\
\hline & A/B & $0.32 \pm 0.04$ & $0.31 \pm 0.04$ & 0.228 \\
\hline & $C / D$ & $0.41 \pm 0.07$ & $0.41 \pm 0.07$ & 0.614 \\
\hline \multicolumn{5}{|c|}{$\begin{array}{l}\text { The mean and standard deviations are shown in millimeters. } \\
\text { The Mann-Whitney } U \text { test was used in comparing the statistically significance } \\
\text { of the difference between the sides. }\end{array}$} \\
\hline
\end{tabular}


Several studies in the literature have examined the effects of MF with different purposes, methods, and landmarks and on populations with different jaw relationships or age groups $(9,13,15,16)$. In the study of Matundu et al. (15) on dry adult human jaws in the Malawi population, the mean distance of the MF was $11.36 \mathrm{~mm}$ from the posterior margin

Table 2. Morphometric measurements of dentate and edentate mandibles according to gender

\begin{tabular}{|c|c|c|c|c|}
\hline & & Female & Male & p \\
\hline \multirow{6}{*}{ Dentate } & A & $19.72 \pm 3.35$ & $19.93 \pm 4.20$ & 0.976 \\
\hline & B & $49.54 \pm 5.20$ & $52.87 \pm 4.32$ & $<0.001^{*}$ \\
\hline & C & $12.68 \pm 1.90$ & $13.27 \pm 1.79$ & $0.005^{*}$ \\
\hline & D & $27.96 \pm 3.08$ & $29.49 \pm 3.41$ & $<0.001^{*}$ \\
\hline & $A / B$ & $0.40 \pm 0.06$ & $0.38 \pm 0.07$ & $0.012^{*}$ \\
\hline & $C / D$ & $0.45 \pm 0.05$ & $0.45 \pm 0.06$ & 0.913 \\
\hline \multirow{6}{*}{ Edentate } & A & $16.21 \pm 2.38$ & $15.02 \pm 2.58$ & $<0.001^{*}$ \\
\hline & B & $52.09 \pm 4.14$ & $47.16 \pm 4.02$ & $<0.001^{*}$ \\
\hline & C & $12.15 \pm 2.52$ & $10.63 \pm 2.24$ & $<0.001^{*}$ \\
\hline & $D$ & $29.05 \pm 3.33$ & $26.60 \pm 3.36$ & $<0.001^{*}$ \\
\hline & $A / B$ & $0.31 \pm 0.39$ & $0.32 \pm 0.43$ & 0.407 \\
\hline & $C / D$ & $0.42 \pm 0.72$ & $0.40 \pm 0.06$ & $0.044^{*}$ \\
\hline \multicolumn{5}{|c|}{$\begin{array}{l}\text { The mean and standard deviations are shown in millimeters. } \\
\text { The Mann-Whitney } U \text { test was used in comparing the statistically significance } \\
\text { of the difference between the genders. } \\
\text { "There is a statistically significant difference between the groups }\end{array}$} \\
\hline
\end{tabular}

of mandibular ramus and $20.85 \mathrm{~mm}$ from the anterior margin. The distance between mandibular notch and MF was 23.7 $\mathrm{mm}$, and the distance between mandibular base and MF was $28.16 \mathrm{~mm}$. They reported that no mandibular asymmetry was observed (15). In Sevmez et al. (13) CT study on 300 adult Turkish individuals, the mean distance of the MF was 14.05 $\mathrm{mm}$ from the posterior margin of mandibular ramus and 20.85 $\mathrm{mm}$ from the anterior margin. And horizontal and vertical distances of mandibular ramus were $32.99 \mathrm{~mm}$ and 23.43 $\mathrm{mm}$, respectively. It was reported that mandibular asymmetry was not observed in their study, but a statistical difference between the genders was determined in all parameters (13). In a study with 224 Jordanian individuals, Al-Shayyab (16) determined that the mean distance of the MF from the posterior margin, anterior margin, mandibular notch and mandibular base were $13.19 \mathrm{~mm}, 17.53 \mathrm{~mm}, 19.23 \mathrm{~mm}$, and $25.6 \mathrm{~mm}$, respectively, on CT radiographs. It was suggested by Al-Shayyab (16) that the location of the MF was significantly variable according to age, without divergence according to the side and gender. In Satir's (9) study comparing mandibular morphometry of individuals with Down syndrome and normal individuals in 2019, it was stated that the measurements made in individuals with Down syndrome were shorter than in the normal individuals. In addition, when they evaluated the measurement of mandibles according to gender and sides in both groups, they stated that there was no statistically significant difference. However, it was reported for individuals with Down syndrome that the morphometry of the mandibular foramen was variable, which results from developmental retardation or the characteristic features of the disease (9).

A few studies in the literature, similar to our study, examined the location and course of the mandibular foramen in patients $(12,17,18,19,20,21,22)$. Prado et al. (12) analyzed a total of 159 ( 80 dentate and 79 edentate) dry adult mandibles. As a result of this analysis, while they did not determine an asymmetry between the sides in both mandible groups, they determined that the horizontal and vertical lengths were higher in the dentate mandibles (12). Captier et al. (21) measured a total of 83 ( 60 dentate and 23 edentate) dry adult mandibles. They reported that the mean distance between mandibular notch and MF was $29.76 \mathrm{~mm}$, and distance of the

Table 3. Morphometric measurements of dentate and edentate mandibles

\begin{tabular}{|l|l|l|l|l|l|l|}
\hline & A & B & C & D & A/B & C/D \\
\hline Dentate & $19.83 \pm 4.04$ & $51.34 \pm 5.02$ & $12.99 \pm 1.87$ & $28.79 \pm 3.49$ & $0.39 \pm 0.07$ & $0.45 \pm 0.06$ \\
\hline Edentate & $15.67 \pm 2.54$ & $49.87 \pm 4.76$ & $11.47 \pm 2.51$ & $27.94 \pm 3.55$ & $0.31 \pm 0.41$ & $0.41 \pm 0.07$ \\
\hline$p$ & $<0.001^{*}$ & $0.002^{*}$ & $<0.001^{*}$ & $0.014^{*}$ & $<0.001^{*}$ & $<0.001^{*}$ \\
\hline
\end{tabular}

The mean and standard deviations are shown in millimeters.

The Mann-Whitney $U$ test was used to compare the statistical significance of the difference between the mandible groups.

*There is a statistically significant difference between the groups 
MF from the posterior margin of mandibular ramus was 15.4 $\mathrm{mm}$. They showed that there was no asymmetry between the dentate and edentate mandible groups and between the parties (21). In the radiography study of Merrot et al. (22) on 106 individuals (65 edentate and 41 dentate), it was determined that while the vertical distance was shorter in edentulous mandibles compared to dentate mandibles, there was no statistically significant difference in their study. In the studies of Hayward et al. (17), Doual et al. (18), Raustia and Salonen (19), and Oğuz and Bozkir (20), it was reported that when dentate and edentate cases were compared, the horizontal distance was found to be statistically shorter in edentate mandibles than in dentate mandibles. In our study, the distance between mandibular foramen and mandibular ramus and the distance between the anterior and posterior edge of the mandibular ramus were found to be compatible with the literature. Although Merrot et al. (22) and Captier et al. (21) found the vertical distance to be shorter in edentulous mandibles than in dentate mandibles, Prado et al. (12) did not find a statistically significant difference in their study $(21,22)$. Acoording to our results, it was found to be shorter than the dentate mandibles in the distance from mandibular foramen to the mandibular notch and the distance between the mandibular notch and the base of mandible, and it was compatible with the studies of Merrot et al. (22) and Captier et al. (21). Antero-posterior narrowing can be explained by tooth loss, reduced chewing load transferred to the alveolar portion of the mandible, and bone resorption of the ramus of the mandible $(18,19)$. The distance from mandibular foramen to the mandibular notch in geriatric people decreases due to mandibular ramus resorption as a consequence of decline in muscular activity and remodeling of the condylar and coronoid processes (22). The factors mentioned above can be shown as an explanation of the changes of the mandibular morphometry in edentate cases.

In our study, $A$ and $D$ measurements and $A B$ ratio in dentate mandibles and $B, C, D$ measurements and $A B, C D$ ratios in edentate mandibles were larger on the right side. These results show that asymmetry in mandibular foramen morphology can be seen even in the same individuals. Contrary to our study, no differences were observed between the sides of the mandible in literature studies. It could be said that this asymmetry is due to the force difference between the masticatory muscles or the existing head asymmetry (19).

The changes in morphometers of mandibular foramen were examined in the studies of Merrot et al. (22) and Sevmez et al. (13) and they determined that the length and width of the mandibular ramus were statistically longer in males than in females. In our study, when the measurements were compared by gender, the $B, C, D$ measurements and $A B$ ratio of male dentate mandibles were statistically higher than those of females, no difference was found in edentulous mandible measurements by gender. Most of mandible measurements were found larger in males in healthy people. However, contrary to what is expected in edentate cases, male mandible measurements were determined not to be larger than thoseof females. Considering that, we can declare that the gender factor is ineffective in the change of mandibular morphometry due to tooth loss.

\section{Study Limitations}

In our study, we faced limitations due to the low mean age of the control group and the lack of some demographic information. In addition, due to the diversity of the scope of the studies in the literature, a common goal could not be focused on. For this reason, we report that our work can be improved with some modifications and additions.

\section{Conclusion}

It was determined that mandible measurements of dentate cases were larger than edentate mandible, and mandibular ramus can be asymmetrical and ramus morphometry may be affected by gender within the clinical syndrome. Our study, which examined the effect of gender, lateralization and tooth loss on mandible morphometry, was a research that contributed to the current literature with its scope and quality. Furthermore, we believe that results of this study will make a great contribution to surgical and clinical branches.

\section{Ethics}

Ethics Committee Approval: The study was carried out as a retrospective archive search in accordance with the Declaration of Helsinki after obtaining Approval from the Local Ethics Committee of Afyonkarahisar University (KAEK/2015/09-240).

Informed Consent: In retrospective archive search, it is not obligatory to obtain patient consent.

Peer-review: Internally peer-reviewed.

\section{Authorship Contributions}

Concept: A.B., O.T., E.K., Design: A.B., O.T., E.K., Data Collection or Processing: A.B., O.T., H.G., E.K., Analysis or Interpretation: A.B., H.G., Literature Search: A.B., Writing: A.B., O.T.

Conflict of Interest: No conflict of interest was declared by the authors.

Financial Disclosure: The authors declared that this study received no financial support. 


\section{References}

1. Buch HA. Clinical anatomy of inferior alveolar nerve block anesthesia. Clin Anat. 2011;24:515-517. [Crossref]

2. Lipski M, Tomaszewska IM, Lipska W, Lis GJ, Tomaszewski KA. The mandible and its foramen: anatomy, anthropology, embryology and resulting clinical implications. Folia Morphol (Warsz). 2013;72:285-292. [Crossref]

3. Peker I, Gungor K, Semiz M, Tekdemir I. Localization of mental and mandibular foramens on the conventional and digital panoramic images. Coll Antropol. 2009;33:857-862. [Crossref]

4. Tsuji Y, Muto T, Kawakami J, Takeda S. Computed tomographic analysis of the position and course of the mandibular canal: Relevance to the sagittal split ramus osteotomy. Int J Oral Maxillofac Surg. 2005;34:243-246. [Crossref]

5. Eryiğit Ö, Turamanlar O, Ünal M, Kaçar M. Evaluation of mandibular foramen localization through three dimensional computed tomography in pediatric population. Sağlık Akademisi Kastamonu. 2019;4:225-242. [Crossref]

6. Yu IH, Wong YK. Evaluation of mandibular anatomy related to sagittal split ramus osteotomy using 3-dimensional computed tomography scan images. Int J Oral Maxillofac Surg. 2008;37:521-528. [Crossref]

7. Ueki K, Okabe K, Miyazaki M, Mukozawa A, Marukawa K, Nakagawa K, et al. Position of mandibular canal and ramus morphology before and after sagittal split ramus osteotomy. J Oral Maxillofac Surg. 2010;68:17951801. [Crossref]

8. Ma J, Lu L. Computed tomography morphology of the mandibular ramus at the lingual plane in patients with mandibular hyperplasia. Int J Oral Maxillofac Surg. 2009;38:823-826. [Crossref]

9. Satir S. Determination of mandibular morphology in a turkish population with down syndrome using panoramic radiography. BMC Oral Health. 2019;19:1-7. [Crossref]

10. Valdec S, Borm JM, Casparis S, Damerau G, Locher M, Stadlinger B. Vestibular bone thickness of the mandible in relation to the mandibular canal-a retrospective CBCT-based study. Int J Implant Dent. 2019;5:37. [Crossref]

11. Chrcanovic BR, de Carvalho Machado V, Gjelvold B. A morphometric analysis of the mandibular canal by cone beam computed tomography and its relevance to the sagittal split ramus osteotomy. Oral Maxillofac Surg. 2016;20:183-190. [Crossref]

12. Prado FB, Groppo FC, Volpato MC, Caria PHF. Morphological changes in the position of the mandibular foramen in dentate and edentate Brazilian subjects. Clin Anat. 2010;23:394-398. [Crossref]

13. Sevmez F, Orhan M, Bahşi I, Yalçin ED. Examination of the Safe Zone in Mandibular Ramus Osteotomies. J Craniofac Surg. 2021;32:2219-2222. [Crossref]

14. Hedderich DM, Spiro JE, Goldhardt O, Kaesmacher J, Wiestler B, Yakushev I, et al. Increasing diagnostic accuracy of mild cognitive impairment due to Alzheimer's disease by user-independent, web-based whole-brain volumetry.J Alzheimer's Dis. 2018;65:1459-1467. [Crossref]

15. Matundu B, Adefolaju GA, Manda J, Mwakikunga A. A morphometric study of the mandibular foramen in dry adult human mandibles in a black malawian population. Int J Morphol. 2021;39:390-395. [Crossref]

16. Al-Shayyab MH.A simple method to locate mandibular foramen with conebeam computed tomography and its relevance to oral and maxillofacial surgery: a radio-anatomical study. Surg Radiol Anat. 2018;40:625-634 [Crossref]

17. Hayward J, Richardson E, Malhotra S. The mandibular foramen: Its anteroposterior position. Oral Surg Oral Med Oral Pathol. 1977;44:837843. [Crossref]

18. Doual J, Ferri J, Laude M. The influence of senescence on craniofacial and cervical morphology in humans. Surg Radiol Anat. 1997;19:175-183. [Crossref]

19. Raustia AM, Salonen MAM. Gonial angles and condylar and ramus height of the mandible in complete denture wearers-a panoramic radiograph study. J Oral Rehabil. 2008;24:512-516. [Crossref]

20. Oguz O, Bozkir MG. Evaluation of location of mandibular and mental for foramina in dry, young, adult human male, dentulous mandibles. West Indian Med J. 2002;51:14-16. [Crossref]

21. Captier G, Lethuilier J, Oussaid M, Canovas F, Bonnel F. Neural symmetry and functional asymmetry of the mandible. Surg Radiol Anat. 2006;28:379386. [Crossref]

22. Merrot O, Vacher C, Merrot S, Godlewski G, Frigard B, Goudot P. Changes in the edentate mandible in the elderly. Surg Radiol Anat. 2005;27:265-270. [Crossref] 